\title{
Geotechnical evaluation of the east wall of the Cerro Corona Pit
}

\author{
J Dueñas Gold Fields, Peru \\ G Becerra Gold Fields, Peru \\ R Ordoñez Gold Fields, Peru \\ PG Andrews Gold Fields Australia Pty Ltd, Australia
}

\begin{abstract}
This document describes the methodology applied to evaluate the anomalous deformation that began to develop in the east wall of the Cerro Corona pit; between levels 3,760 to 3,840 (masl). The main causes of the increase in deformation were associated with the presence of large structures that cross the slope (geological faults), the effect of groundwater, surface water (runoff), and the predominant lithology at these levels (mainly argillic alteration). The deformation began to increase from May 2017 until March 2019, where accumulated deformation rates of up to $1.60 \mathrm{~m}$ have been recorded in the robotic station, and up to $1.40 \mathrm{~m}$ with radar.
\end{abstract}

A comprehensive geotechnical study was undertaken which has identified two steeply dipping structural systems (sub-vertical structures) that cross the east wall creating structural blocks (compartmentalised structures) that have facilitated the accumulation of both ground and surface water. In the formation of these structures, shear zones associated with the argillic alteration have been generated; allowing the formation of very low permeability aquitards which form fault bounded blocks. These blocks have generated high levels of groundwater compared to the levels outside the faults, and, consequently, have triggered the increase in deformation (due to anomalous increases in pore pressure). Using historical groundwater conditions, the stability analyses indicated that the slope was marginally stable, where the Safety Factors (or Factor of Safety, FoS) obtained (through numerical modelling) were between 1.1 and 1.2, which are below the Gold Fields acceptability criteria.

To ensure that the slope design meets the established acceptability criteria, a depressurisation program was developed in this sector, where approximately 1,000 $\mathrm{m}$ of sub-horizontal drains have been drilled to depressurise the east wall, focusing on structural blocks and lithological contacts. The results of depressurisation programmes were very good, and consequently, the deformation rate has decreased to return to its normal deformation values. The results obtained from the stability analysis (current and life-ofmine (LOM)) under depressurisation conditions are well above the FoS acceptability criteria.

Finally, the detailed geotechnical study and depressurisation has allowed the increase of the inter-ramp angle by $2^{\circ}$ in the current LOM plan, and to add more ore reserves in $~ 1.4$ Mtonnes.

Keywords: rock mass characterisation, slope stability optimisation, shear strength reduction, weak rock mass

\section{Introduction}

The copper and gold deposit of Cerro Corona is a porphyry-style mineralisation housed in a sub-vertical cylindrical diorite porphyry of $600-700 \mathrm{~m}$ in diameter (body similar to a pipe) located in Cretaceous age carbonate rocks. The geological model expands on this simple lithological model based on hydrothermal alteration, with marble representing the alteration product of the limestone in the contact area of the intrusive. Alteration zoning is typical of a porphyry system, with decreasing silicification outward from the central silicified core of the intrusive. 
The following alteration categories for the Diorite that represent the outward zoning of hydrothermal alteration and are based primarily on the alteration minerals assemblage, but the mechanical characteristics that result from the alteration are of primary importance for slope performance, such as: Silica (Silicic alteration), Potassic (beyond the zone of silicification), Propylitic, Argillic 1, Argillic 2 and Argillic 3, as shown in Figure 1.

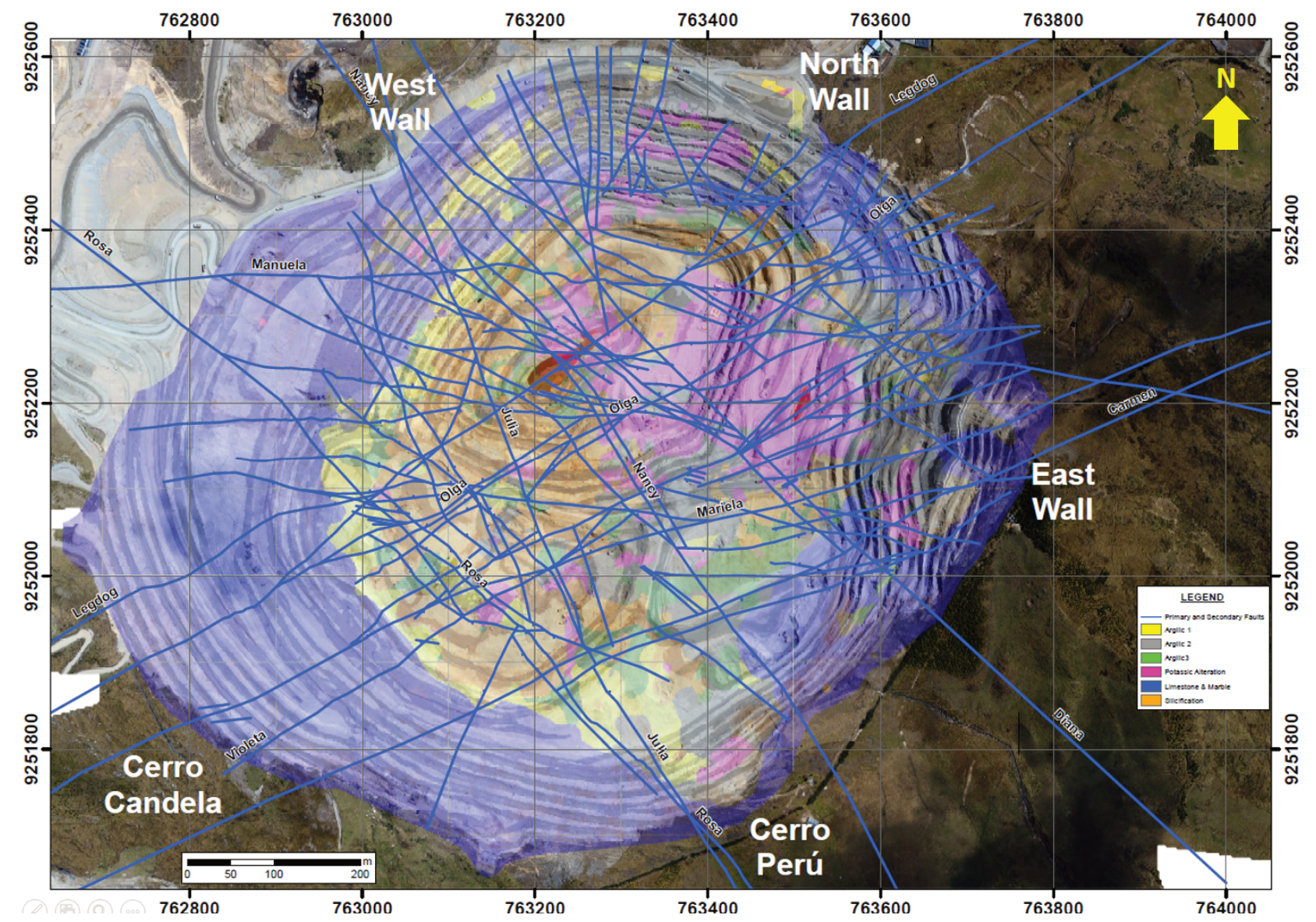

Figure 1 Cerro Corona's geology showing various types of hydrothermal alterations that predominate in open pit

In the east wall, the argillic alteration predominates within the intrusive near the limestone rock contacts and decreases in intensity with the distance of the contacts. Intrusive contacts/carbonates are fault contacts that are characterised by an intense alteration of the clay and shear zones. Highly fractured 'non-competent' (NC) zones are common near fault contacts. The main structures that were identified in the geological model include sub-vertical faults that generally strike either northwest (older faults) or the northeast (younger faults), as shown in Figure 1.

\subsection{Historical instabilities}

The slope instability developed within the argillic alteration zone classified as non-competent Argillic 2 (ARG2-NC) on the edges of the Diorite. This initial movement was stabilised by the construction of a buttress at level 3820. As the mine deepened, slope deformation continued and was associated with the lithology mainly of ARG2-NC; which extends from level $3820 \mathrm{RL}$ to the current ramp to level $3760 \mathrm{RL}$ at the north end of the slope. In order to reduce the deformation and mitigation of runoff water, improvements in surface drainage were implemented, which included the construction of trenches with controlled discharges in this sector of ARG2-NC material. However, the deformation rate only decreased slightly.

A comprehensive geotechnical review was undertaken to identify the main causes of the anomalous deformation of this part of the slope. This detailed work included geotechnical mapping at the bench level, 
review of geotechnical instrumentation data, kinematic analyses, and a review and update of the 3D geotechnical model.

Two systems of sub-vertical faults that cross the slope were mapped and strike between $070^{\circ}$ and $090^{\circ}$. These have formed structural blocks (creating clay bound compartments) that have allowed the accumulation of water. In the interaction of these structures, shear zones associated with the argillic alteration have been formed, where aquitards of very low permeability have been formed. Within these blocks, groundwater has accumulated more due to surface water infiltration and trapped groundwater, generating higher levels of groundwater compared to groundwater levels outside the blocks, and consequently, the pore pressure increased which then induced further deformation.

\section{Geotechnical units and rock mass assessment}

\subsection{Geotechnical units}

Rock mass rating (RMR) and unconfined compressive strength (UCS) block models were used to develop estimates of rock mass strength. A block model based on geotechnical units has also been added, which considers lithology and alteration and is used to predict the distributions of geotechnical units within and behind the pit slopes. Current block models are updated annually to incorporate any new drilling information. The geotechnical block model is also reconciled with the pit bench mapping and can be considered rational (based on the geological model) and defensible (incorporates all relevant geotechnical data and is regularly updated).

The good correlation obtained with the mapping indicates that the geotechnical block model is reasonably reliable as a predictive model; and the use of these block models improves the reliability of predictions of geotechnical conditions near the slopes of the pit. Table 1 shows the summary of the geotechnical units of the pit and the corresponding geometric design for each geotechnical unit:

Table $1 \quad$ Geotechnical units for Cerro Corona mine

\begin{tabular}{|c|c|c|c|c|c|c|c|c|c|}
\hline $\begin{array}{l}\text { Geotechnical } \\
\text { unit }\end{array}$ & Code & Colour & $\begin{array}{l}\text { RMR* } \\
\text { range }\end{array}$ & $\begin{array}{l}\text { UCS* } \\
\text { range } \\
\text { (MPa) }\end{array}$ & $\begin{array}{l}\text { IRA* } \\
\left({ }^{\circ}\right)\end{array}$ & $\begin{array}{c}\text { BFA* } \\
\left({ }^{\circ}\right)\end{array}$ & $\begin{array}{c}\text { Bench } \\
\text { height } \\
\text { (m) }\end{array}$ & $\begin{array}{l}\text { Design } \\
\text { berm width } \\
\text { (m) }\end{array}$ & $\begin{array}{c}\text { Ritchie } \\
\text { berm } \\
\text { width }(\mathrm{m})\end{array}$ \\
\hline Argillic $1 \mathrm{NC}$ & A1-NC & & $14-35$ & $11-27$ & 40 & 65 & 10 & 7.3 & 6.5 \\
\hline Argillic $1 \mathrm{C}$ & A1-C & & $35-48$ & $27-39$ & 46 & 65 & 20 & 10 & 8.5 \\
\hline Argillic 2 NC & $\mathrm{A} 2-\mathrm{NC}$ & & $10-23$ & $0-6$ & 32 & 60 & 10 & 10.2 & 6.5 \\
\hline Argillic 2 C & $A 2-C$ & & $23-37$ & $6-31$ & 39 & 65 & 10 & 7.7 & 6.5 \\
\hline Argillic 3 NC & A3 & & $10-28$ & $0-17$ & 32 & 65 & 10 & 11.3 & 6.5 \\
\hline Potassic NC & $\mathrm{K}-\mathrm{NC}$ & & $21-43$ & $6-39$ & 49 & 70 & 20 & 10.1 & 8.5 \\
\hline Potassic C & $\mathrm{K}-\mathrm{C}$ & & $43-80$ & 39-92 & 53 & 75 & 20 & 9.7 & 8.5 \\
\hline Silicified C & $S$ & & $43-70$ & $46-86$ & 53 & 75 & 20 & 9.7 & 8.5 \\
\hline Limestone NC & $\mathrm{C}-\mathrm{NC}$ & & $19-41$ & $6-31$ & 43 & 75 & 10 & 8 & 6.5 \\
\hline Limestone $\mathrm{C}$ & $\mathrm{C}-\mathrm{C}$ & & $41-70$ & $31-69$ & 54 & 75 & 20 & 9.2 & 8.5 \\
\hline
\end{tabular}

$\mathrm{RMR}=$ rock mass rating, UCS = unconfined compressive strength, IRA = inter ramp angle, $\mathrm{BFA}=$ batter face angle

\subsection{Rock mass assessment}

In the east wall, materials that have a similar behaviour to the ground predominate due to their low shear strength. These include the areas of Argillic 2, Argillic 3 and the non-competent contact area. Table 2 shows 
the geotechnical properties for these materials. The geomechanical properties for the more competent rock have also been characterised, in this case the strength of the rock mass has been modelled according to the Hoek-Brown failure criterion (Hoek et al. 2002), which establishes a non-linear resistance envelope. Table 3 shows the summary of these values.

Table 2 Geotechnical properties used for weak materials

\begin{tabular}{lllccc}
\hline Geotechnical unit & Code & $\begin{array}{l}\text { Strength } \\
\text { envelope }\end{array}$ & $\begin{array}{c}\text { Unit } \\
\text { weight } \\
\left(\mathrm{KN} / \mathbf{m}^{3}\right)\end{array}$ & $\begin{array}{c}\text { Cohesion } \\
(\mathrm{KPa})\end{array}$ & $\begin{array}{c}\text { Phi } \\
\left(\boldsymbol{\varphi}^{\circ}\right)\end{array}$ \\
\hline Not competent argillic 2 & A2-NC & Mohr-Coulomb & 22 & 15 & 34 \\
Argillic 3 & A3 & Mohr-Coulomb & 22 & 15 & 34 \\
Contact zone & - & Mohr-Coulomb & 22 & 0 & 20 \\
\hline
\end{tabular}

Table 3 Geotechnical properties used for rock mass units

\begin{tabular}{lllcc}
\hline Geotechnical unit & Code & Strength envelope & $\begin{array}{c}\text { Unit } \\
\text { weight } \\
\left(\mathbf{K N} / \mathbf{m}^{3}\right)\end{array}$ & $\begin{array}{c}\text { Intact rock } \\
\text { constant (mi) }\end{array}$ \\
\hline Not competent argillic 1 & A1-NC & Gen. Hoek-Brown & 22 & 9 \\
Competent argillic 1 & A1-C & Gen. Hoek-Brown & 24 & 10 \\
Not competent argillic 2 & A2-C & Gen. Hoek-Brown & 22 & 10 \\
Competent argillic 2 & K-NC & Gen. Hoek-Brown & 23 & 10 \\
Competent potassic & K-C & Gen. Hoek-Brown & 26 & 18 \\
Silicified & S & Gen. Hoek-Brown & 25 & 15 \\
Massive silica & SM & Gen. Hoek-Brown & 25 & 15 \\
Not competent limestone & C-NC & Gen. Hoek-Brown & 22 & 10 \\
Competent limestone & C-C & Gen. Hoek-Brown & 27 & 14 \\
\hline
\end{tabular}

Elastic properties were obtained from laboratory tests and in some cases were estimated by empirical relationships. However, these properties were readjusted by means of a calibration process with historical deformation information obtained from prisms and radar data. The redefined properties have been used to execute the life-of-mine (LOM) 2030 scenario for deformation analysis and the SRF (strength reduction factor) method. While the Poisson ratio was estimated from the following empirical correlation (Vásárhelyi \& Kovács 2017):

$$
V=-0.002 \mathrm{GSI}-0.003 \mathrm{mi}+0.457
$$

Tables 4 and 5 summarise the elastic properties used in modelling. 
Table $4 \quad$ Summary of elastic properties

\begin{tabular}{lccccc}
\hline Geotechnical unit & \multicolumn{3}{c}{ Young's modulus (GPa) } & $\begin{array}{c}\sigma_{\mathrm{ci}} \\
\text { design } \\
\text { (MPa) }\end{array}$ & $\begin{array}{c}\text { Young's modulus } \\
\text { design (GPa) }\end{array}$ \\
\hline Not competent argillic 1 & 9 & 24 & 0.38 & 30 & 3.2 \\
Competent argillic 1 & 10 & 41 & 0.34 & 16 & $1.7^{*}$ \\
Not competent argillic 2 & - & - & 0.3 & 10 & 3.3 \\
Competent argillic 2 & 10 & 30 & 0.37 & 5.5 & $1.6^{* *}$ \\
Argillic 3 & - & - & 0.3 & 2 & $0.7^{* *}$ \\
Not competent potassic & 10 & 32 & 0.36 & 68 & 20.8 \\
Competent potassic & 18 & 61 & 0.28 & 26 & $8^{*}$ \\
Silicified & 15 & 56 & 0.3 & 58 & 8.9 \\
Not competent limestone & 10 & 30 & 0.37 & 24 & $3.7^{*}$ \\
Competent limestone & 14 & 55 & 0.3 & 77 & 20 \\
\hline
\end{tabular}

* Estimated from unconfined compressive strength tests. ${ }^{* *}$ Estimate of the module of the competent rock, adjusted for the ratio between $\sigma_{\mathrm{ci}}$ design of the non-competent rock versus the competent rock.

Table 5 Summary of geological strength index (GSI) and Poisson's ratio values

\begin{tabular}{lccc}
\hline Geotechnical unit & mi & GSI & $\begin{array}{c}\text { Rock mass } \\
\text { Poisson }\end{array}$ \\
\hline Not competent argillic 1 & 9 & 24 & 0.38 \\
Competent argillic 1 & 10 & 41 & 0.34 \\
Not competent argillic 2 & - & - & 0.3 \\
Competent argillic 2 & 10 & 30 & 0.37 \\
Argillic 3 & - & - & 0.3 \\
Not competent potassic & 10 & 32 & 0.36 \\
Competent potassic & 18 & 61 & 0.28 \\
Silicified & 15 & 56 & 0.3 \\
Not competent limestone & 10 & 30 & 0.37 \\
Competent limestone & 14 & 55 & 0.3 \\
\hline
\end{tabular}

\subsection{D factor adjustments}

Following the criteria of Hoek (2012), the damage zones (factor D) have been determined according to their proximity to the blasting areas and the type of control applied to the slope areas as shown in Figure 2. The $T$ width of dissociated areas depends on the height of the blasted benches $(\mathrm{H})$ and the type of blasting:

- Production blasting without control, blasting towards free face:

$$
\mathrm{T}=(1.0 \text { to } 1.5){ }^{*} \mathrm{H}
$$

- Production blasting with some control, blasting towards free face:

$$
T=(0.5 \text { to } 1.0) * H
$$




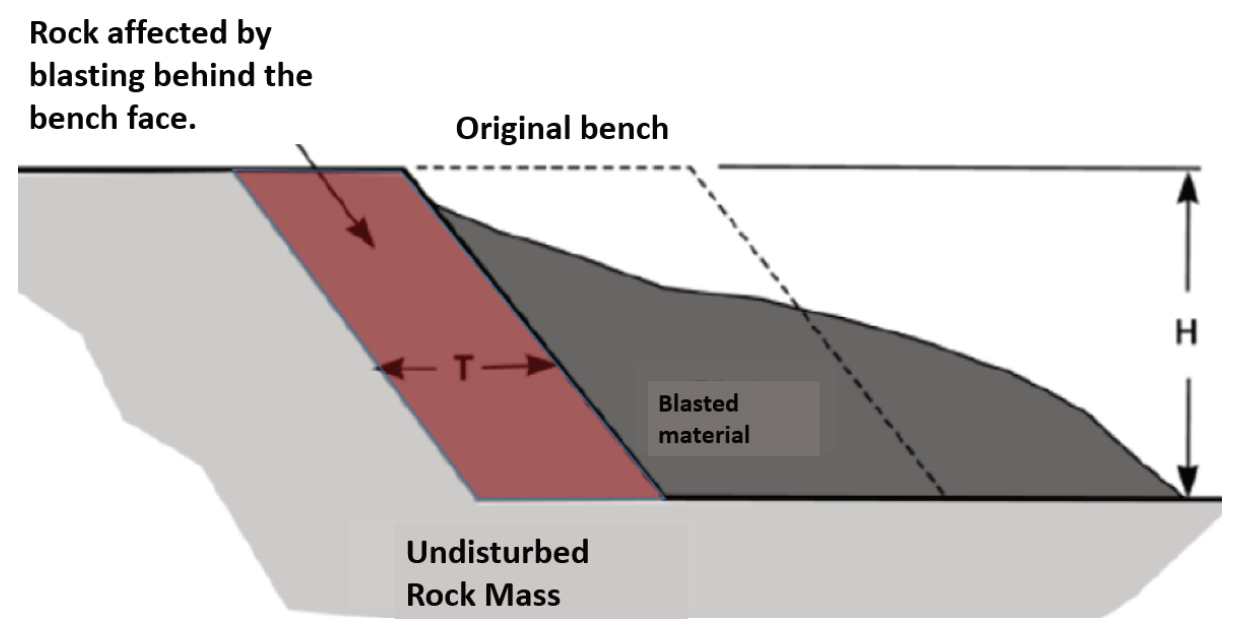

Figure 2 Damage width due to blasting effect

The batter heights at the Cerro Corona pit are between 10 and $20 \mathrm{~m}$ high, as well as controlled production blasting, so the ranges of the damaged area vary between 10 to $20 \mathrm{~m}$, for this case $\mathrm{T}=20$ was taken as $20 \mathrm{~m}$, shown in Figure 3. As a conservative value for our stability analysis, defining the value of factor $D$ as follows:

- Rock without blasting damage (not disturbed): $\mathrm{D}=0$.

- Rock blasting with damage (disturbed): $\mathrm{D}=0.7$.

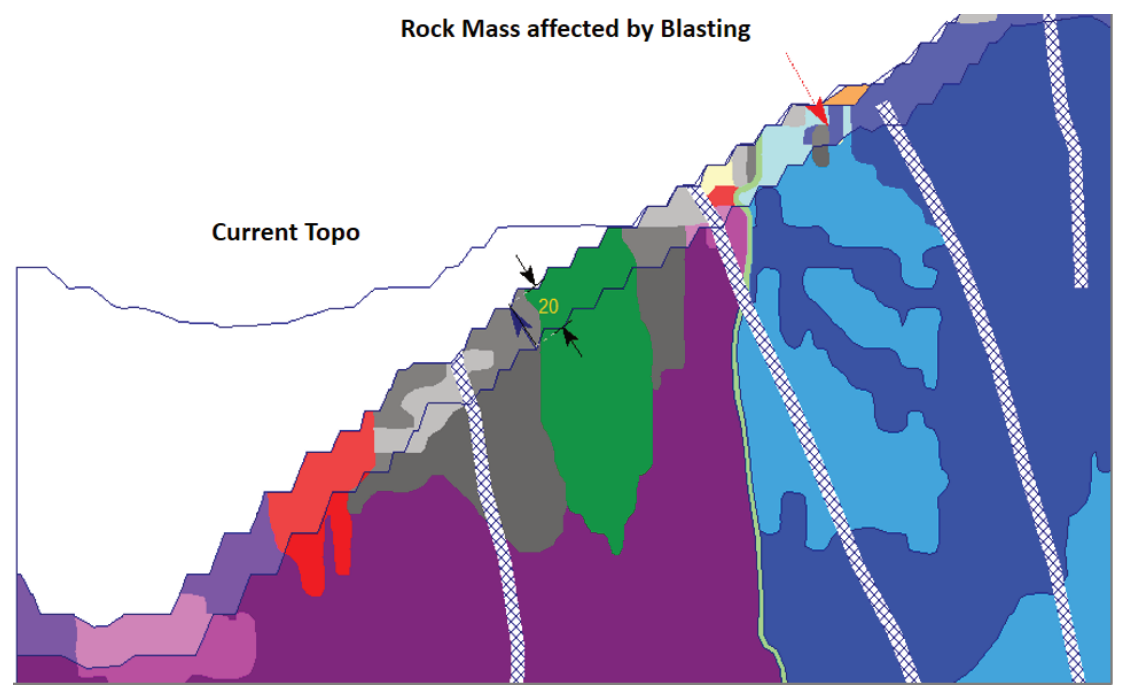

Figure 3 Typical cross-section of disturbance zone with $\mathrm{T}=20 \mathrm{~m}$

\section{Slope monitoring, major structures and groundwater behaviour}

\subsection{Slope monitoring}

The geotechnical monitoring in the open pit of Cerro Corona is performed using a robotic total station and a real-time radar (Figure 4). The results of the monitoring with the robotic station showed an accumulated deformation of up to 1,500 mm, the biggest increase was between October 2017 and May 2018, where the deformation rate reached $4.4 \mathrm{~mm} /$ day between levels 3760 to 3820 masl. Similarly, the results of radar monitoring indicate significant accumulated displacements of up to $1,600 \mathrm{~mm}$ during the last $12 \mathrm{months}$. The displacement trends of the robotic station and the radar are associated with the months of higher rainfall as shown in Figure 5. 


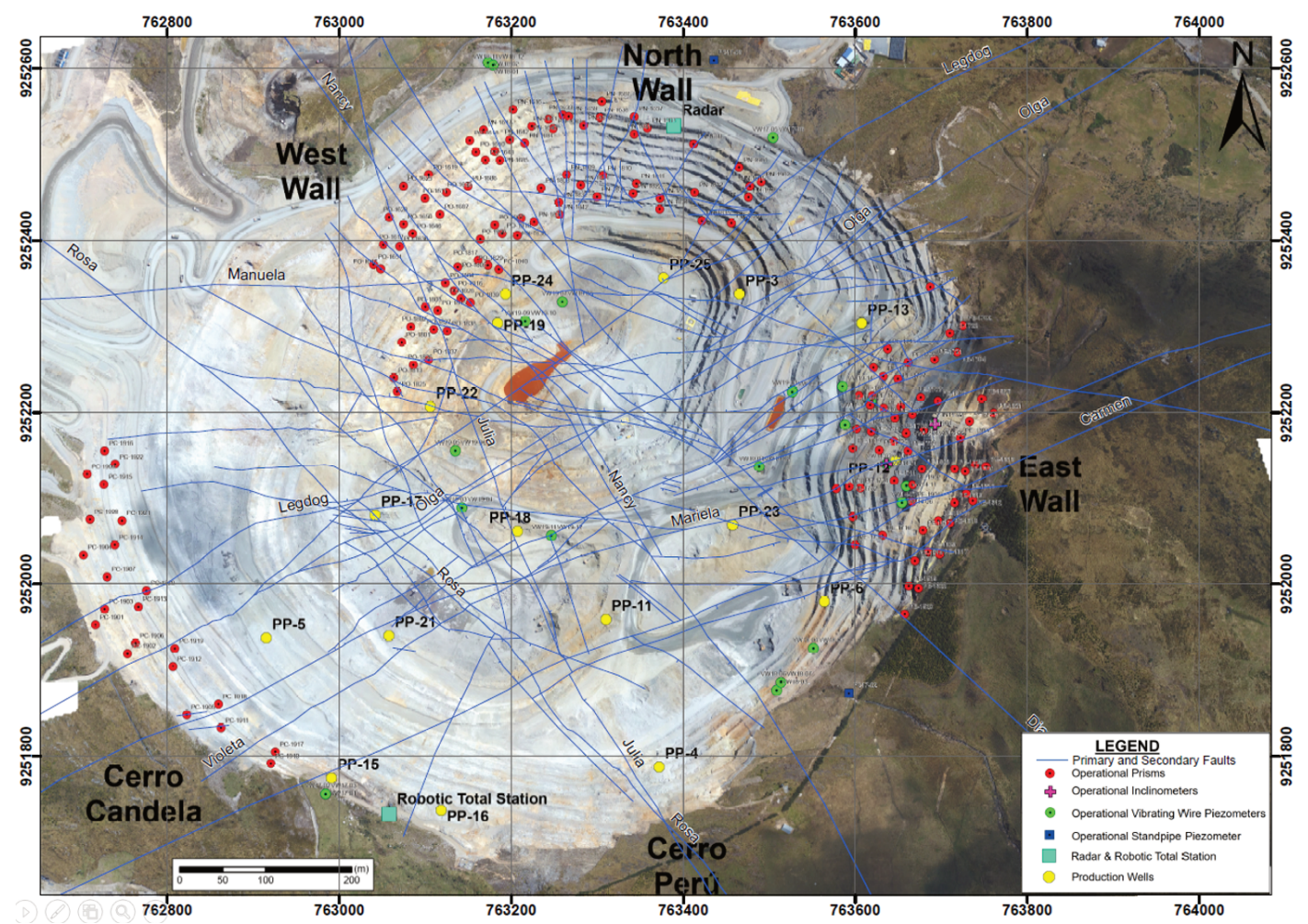

Figure 4 Geotechnical instrumentation distributed around the Cerro Corona open pit
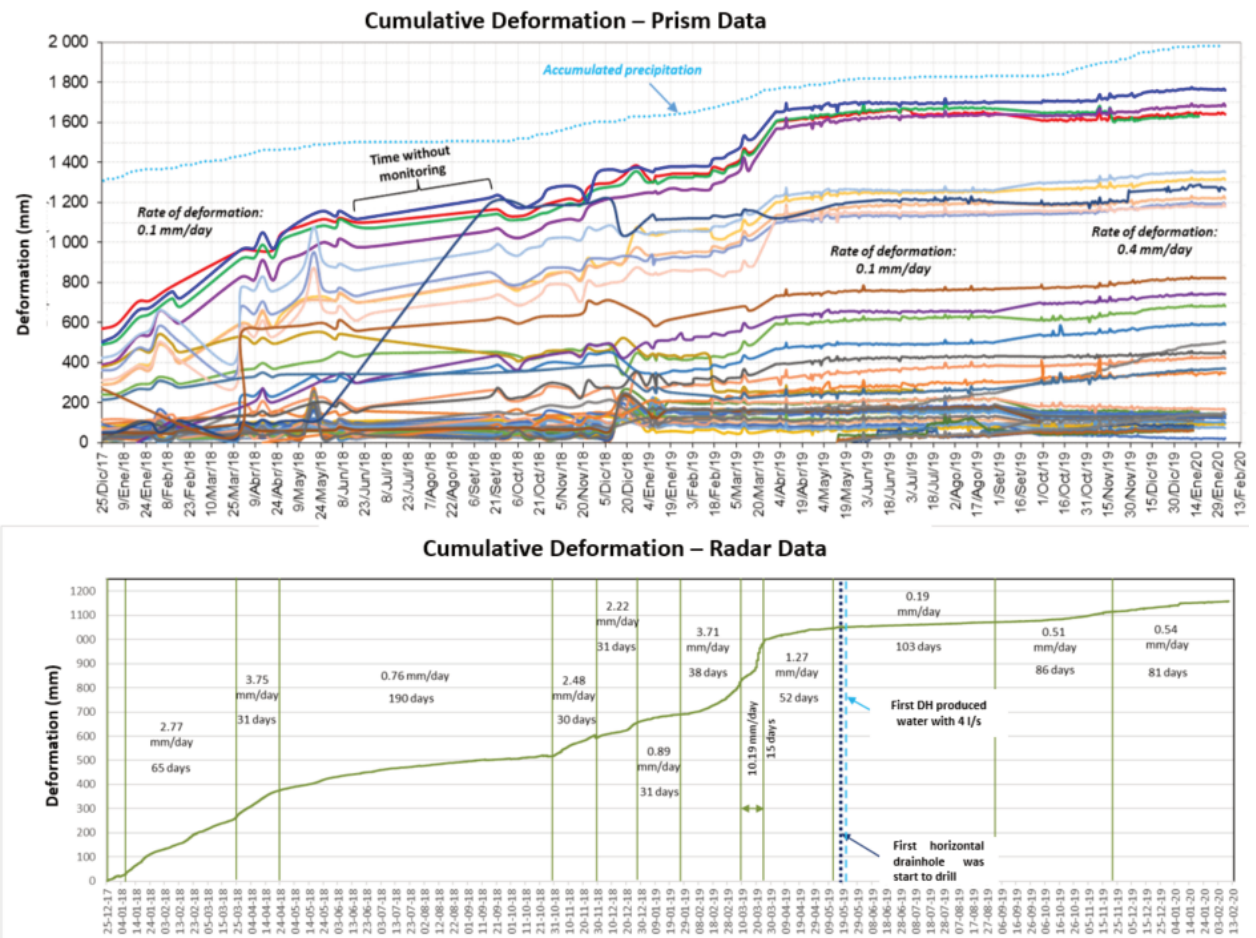

Figure 5 Historical deformation rates on the east wall of the Cerro Corona pit: The upper graph is from prisms data and the bottom is deformation from radar data. Note the different time scales

These deformations were directly associated with the geotechnical units classified as argillic 2 (competent and non-competent) that predominate in the east wall (Figure 1). Historically, in this sector there has been instabilities in the previous mining stages, highlighting in an activation in October 2013, where a failure plane 
was identified in the 3820 bench after the projection of the lithological contact, and as mentioned previously, this was stabilised with a buttress.

\subsection{Major structures}

Over time, the characteristics and geomechanical properties of the discontinuities were evaluated, such that the two systems of steeply dipping faults that cut the slope at an azimuth of $070^{\circ}$ to $090^{\circ}$ have been identified to have created structurally bound blocks and this has also been verified in the updated 3D geotechnical model. The results of the kinematic analysis of the main structures indicate a potential formation and movement of an inverted wedge that does not daylight on the slope faces between the ramp levels.

Due to the interaction of these faults with some minor structures, intense shear zones have been generated and the consequent formation of argillic materials (rich in clay) within the contacts where the permeability in these areas is very low. Consequently, these compartmentalised structures have been created where groundwater is accumulated between the low permeability zones, forming fault bound-blocks that have higher water levels. These blocks are recharged by surface runoff (during the rainy season) thus generating an increase of pore pressure. The high pore pressures then triggered the increase in the slope deformation rate in argillic materials. Higher deformation rates are associated with the rainy season are seen at the intersection of major faults, as detailed in Figures 5 and 6.

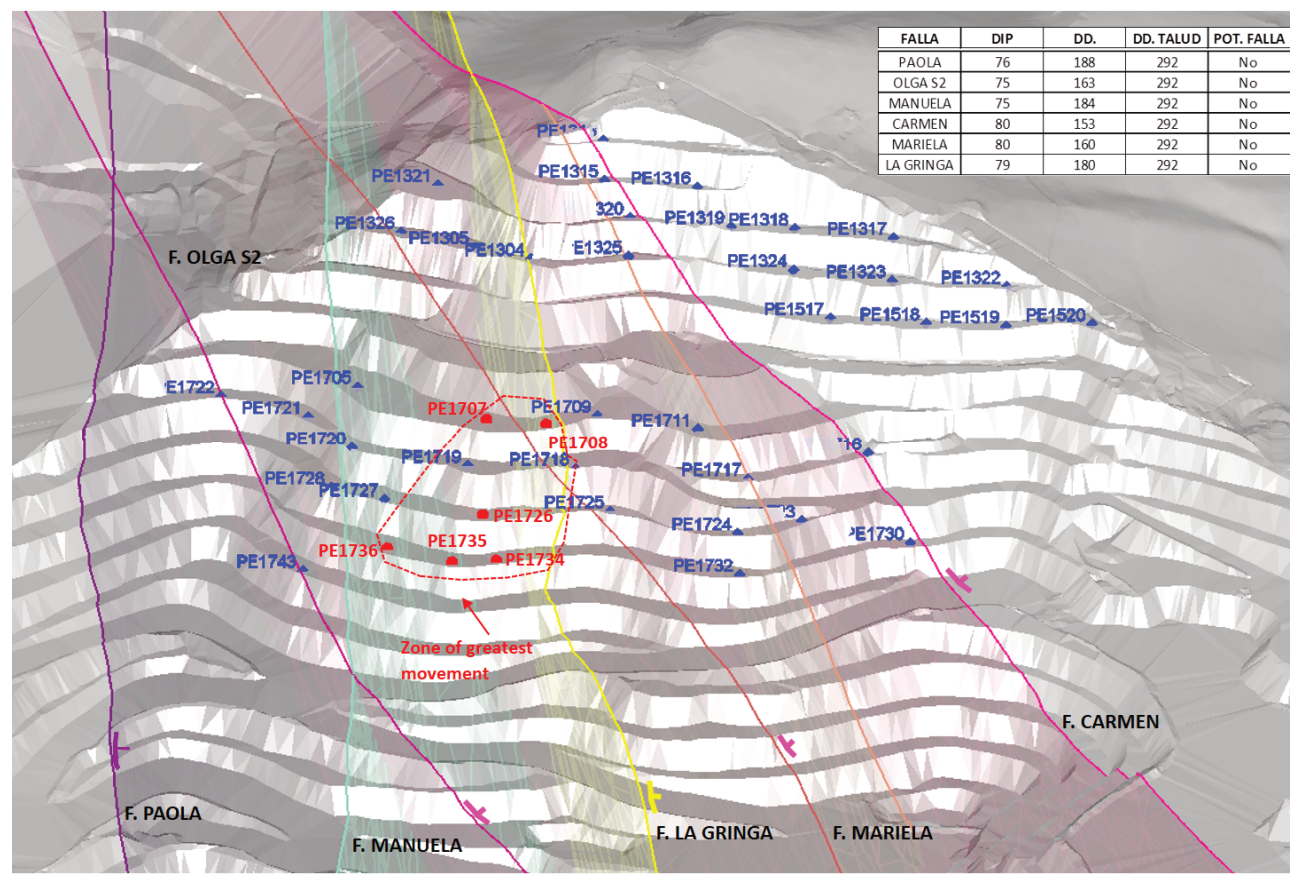

Figure 6 Front view of east wall showing the location of the structures and the location of the prisms with greater movement (red) and those with less movement (blue)

\subsection{Groundwater behaviour}

Consequently, to reduce the anomalous pore pressure and reduce the slope deformation rates, a sub-horizontal drilling program was undertaken to depressurise the east wall. The objective of the drilling was to cross the intersection of the fault bound blocks associated with the argillic material, as detailed in the design of the drains in Figure 7.

The results obtained from sub-horizontal drilling were satisfactory, with maximum flows of up to $6 \mathrm{~L} / \mathrm{s}$ as shown in Table 6. 


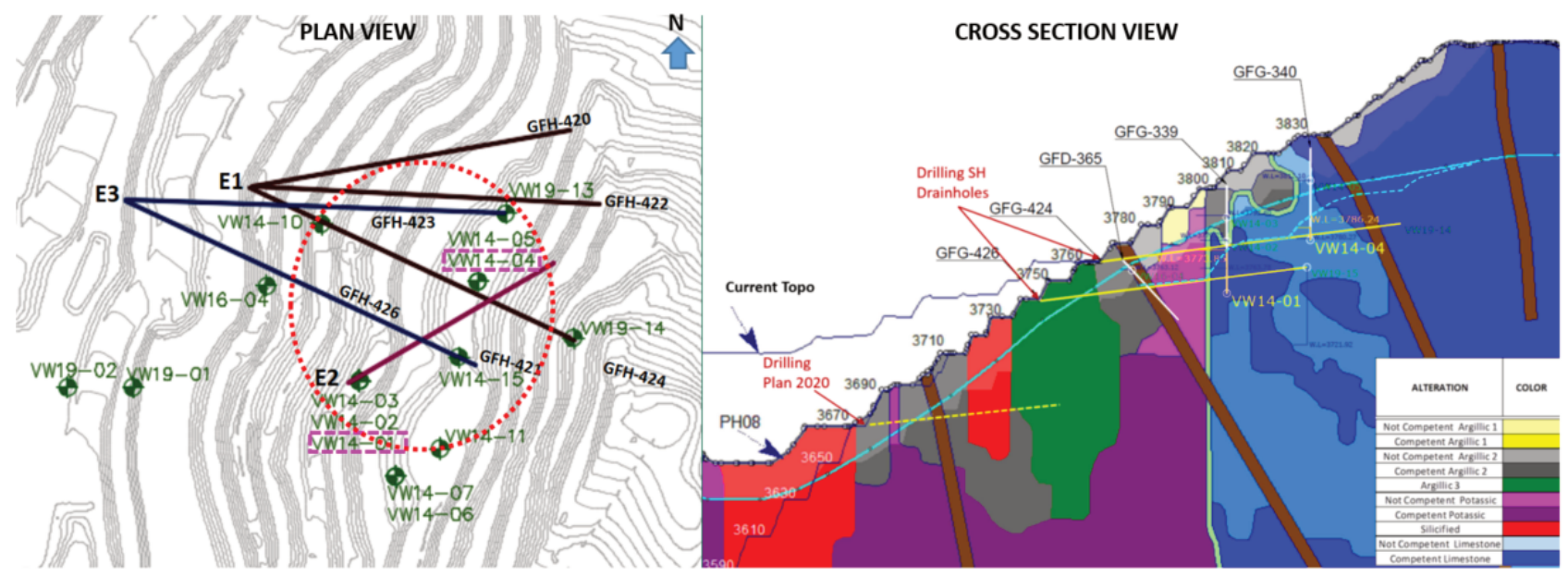

Figure 7 Drilling of sub-horizontal drain holes at east wall slope, on the left view in plan and on the right view in section

Table 6 Flows obtained by drilling sub-horizontal drain holes

\begin{tabular}{llcccccc}
\hline Station & Name & Drill hole & $\begin{array}{c}\text { Final } \\
\text { depth }(\mathbf{m})\end{array}$ & $\begin{array}{c}\text { Az } \\
\left({ }^{\circ}\right)\end{array}$ & $\begin{array}{c}\text { Dip } \\
\left(\mathbf{(}^{\circ}\right)\end{array}$ & $\begin{array}{c}\text { Ground } \\
\text { water }(\mathbf{m})\end{array}$ & $\begin{array}{c}\text { Peak flow } \\
(\mathbf{L} / \mathbf{s})\end{array}$ \\
\hline \multirow{2}{*}{ E1 } & D1 & GFH-420 & 153.4 & 80 & 7 & 73.1 & 0.9 \\
& D2 & GFH-422 & 165.3 & 93 & 7 & 54 & 6 \\
\multirow{2}{*}{ E2 } & D3 & GFH-424 & 170.6 & 115 & 7 & 75 & 3.2 \\
\multirow{2}{*}{ E3 } & D1 & GFH-421 & 113.2 & 60 & 7 & Dry & Dry \\
& D1 & GFH-423 & 180.5 & 92 & 7 & 47.3 & 5 \\
\hline
\end{tabular}

Vibrating wire piezometers were installed on the slope of the east wall in order to assess the behaviour of groundwater levels. The effect of the horizontal drains was observed in piezometers VW14-04 and VW14-01 where the decrease in groundwater level was up to $14 \mathrm{~m}$. However, the location of these piezometers is outside the water filled wedge, which is why groundwater drops have not been as high as expected or that the permeability of argillic material is very low, and consequently, groundwater drops are slow, as shown in Figure 8. 


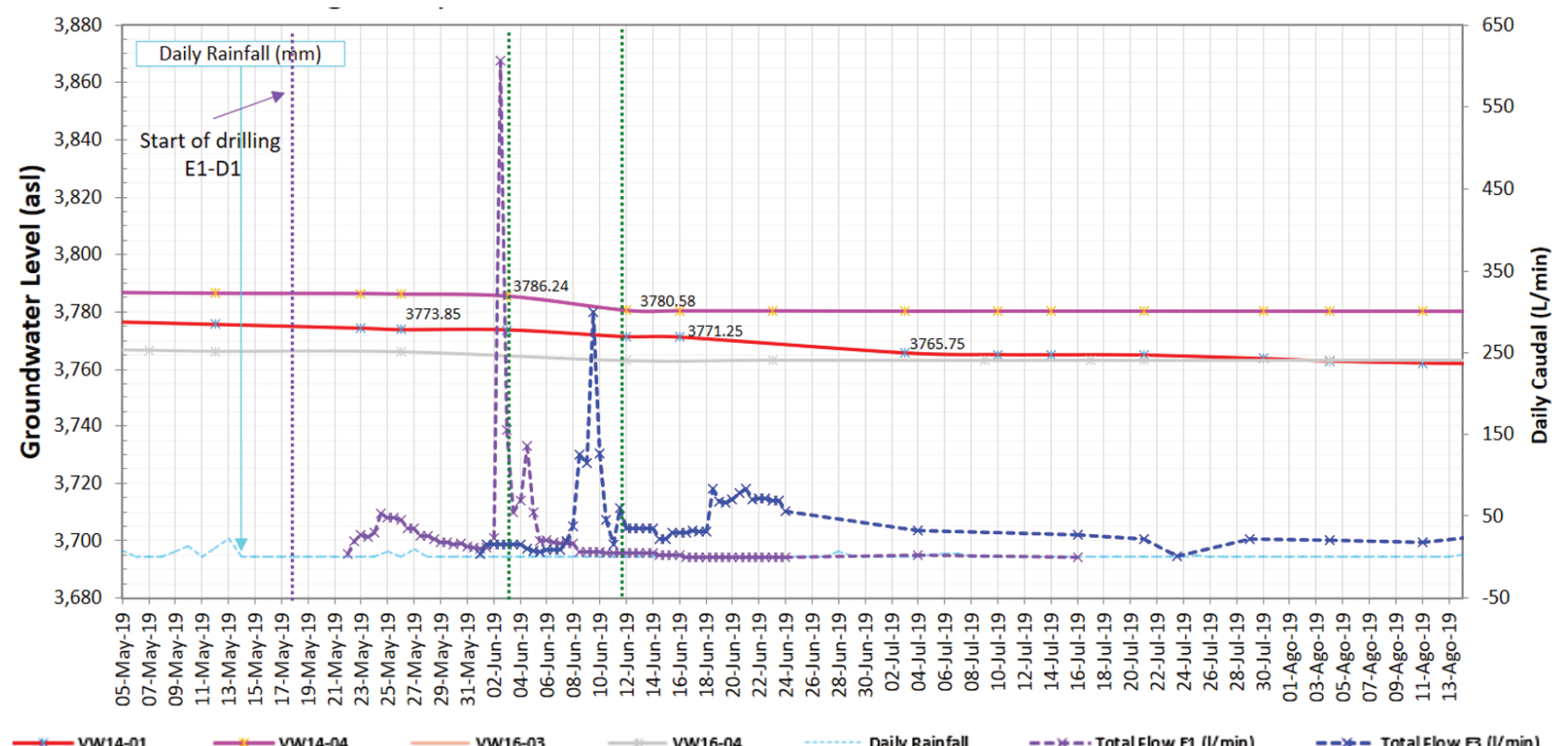

Figure 8 Flow rates obtained from sub-horizontal drain holes and drawdown of groundwater level

Finally, the 3D geotechnical block model was reviewed and updated, which includes all the elements of a 'best geotechnical practices' program. The research, characterisation and development of the 3D model results in a reliable geotechnical model (based on lithological, alteration and structural models). The model that has been developed is based on geotechnical logging and mapping at the bench level, showing a high degree of reliability based on the reconciliation of the geotechnical block model with the geotechnical registration of sub-horizontal drains. The revision and update of the 3D geotechnical model led to the identification of an additional geotechnical unit beyond the slope face, the massive silica (compared to the 2017 model), and this geotechnical unit predominates in the central part of the pit, so it will not interact with the design of the final walls of the open pit.

The update of the 3D geotechnical model, the characterisation of the sub-vertical structures and the behaviour of the groundwater were of vital importance in the evaluation of the geomechanical behaviour of the rock mass in the east wall. Stability analysis and slope design using the 3D geotechnical model provide us with a rational and defensible basis for the optimisation of this area. This, associated with the latest generation geotechnical radar monitoring, provides a reliable basis for risk management, stability interpretation and calibration of numerical models.

\section{$4 \quad$ Slope stability analysis}

Wall stability is a major concern due to the history of instabilities that have occurred and the location of the LOM permanent access ramp within this wall. Slope deformations that developed within the ARG2-NC zones were initially stabilised by building a buttress at level 3820, but radar monitoring indicated that slope deformations continued in the ARG2-NC area below the buttress until the elevation of the current ramp at level 3760 at the north end of the sector. The slope below the ramp was generally developed within the competent potassium alteration $(\mathrm{K}-\mathrm{C})$, which was not identified as a large-scale stability risk.

For the slope stability analysis, the geotechnical team document the most recent version of the model and analyse results to support the current LOM pit slope designs.

Initially Slide ${ }^{\mathrm{TM}}$ software using Limit Equilibrium (LE) methods was used to determine if the Acceptance Criteria of a minimum static Factor of Safety $(\mathrm{FoS})=1.30$, was meet. Also, a pseudo-static analysis requiring a FoS of 1.05 using a design seismic coefficient of $0.85 \mathrm{~g}$ was undertaken. In addition, the RS2 ${ }^{\mathrm{TM}}$ software program using finite element methods was used to determine the FoS using the SRF was completed with satisfactory result. 
Considering the geotechnical study of the east wall in detail and its potential impact on LOM ramp stability, it was necessary to back analyse the historical instability to replicate the conditions of the slope's geomechanical behaviour where the groundwater levels are very close to the slope wall in the rainy season (high pore pressure). Results indicated there was an increase in the deformation rate, mainly in argillic materials.

For this purpose, the RS2 ${ }^{\mathrm{TM}}$ numerical software has been used whereby the FoS has been estimated from the technique of the SRF. The estimated FoS for strength reduction (critical SRF) for the current conditions was 1.18 with an estimated displacement of $0.55 \mathrm{~m}$ per model, with a calibrated groundwater level corresponding to the current conditions (Figure 9).
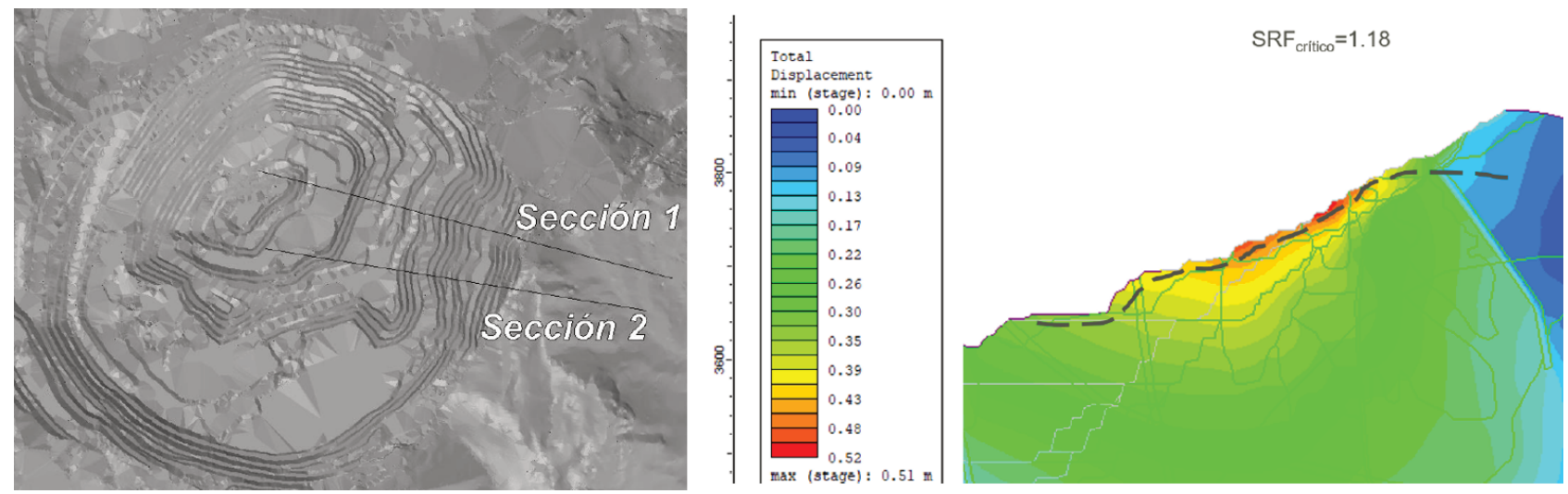

Figure 9 Sensitivity analysis using the strength reduction factor (SRF) technique on the east wall under current conditions (Golder Associates 2019)

With this calibrated result, Golder Associates (2019) developed a predictive analysis of the LOM mining plan, considering the level of groundwater near the slope and away from the slope (depressurised slope), in order to assess future conditions of highwalls. The results are shown in Figure 10.
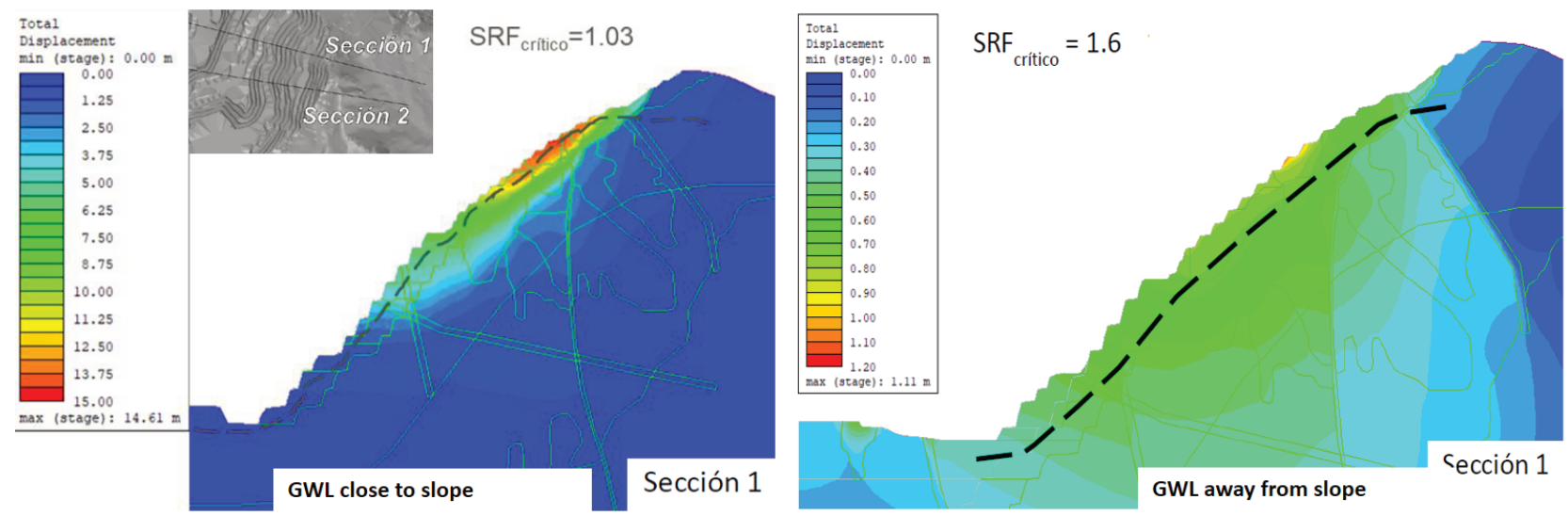

Figure 10 Predictive analysis of the east wall with groundwater levels for the pit life-of-mine (Golder Associates 2019)

The results provided by Golder confirm that the depressurisation of the east wall was necessary to maintain the stability of the slope. Consequently, the decision to depressurise the wall in the current mining conditions was adequately defined and managed by the geotechnical team of Cerro Corona.

The analysis indicated that the overall stability of the slope for the base case would be stable (SRF around 1.2 to 1.3) mainly in the upper part (level 3760 up) due to the predominance of argillic materials (ARG2-NC and ARG-3) and the presence of groundwater near the slope. This condition would progressively worsen with the development of future mining phases until a quasi (or marginally) stable condition with greater displacement 
and instability potential is reached, before the final slope geometry of the mining phase of the LOM plan was achieved.

In order to ensure the overall stability of the upper part of the east wall, all available information has been thoroughly reviewed as discussed in section 2 . The update of the 3D geotechnical block model and the drilling information of the horizontal drains has allowed us to identify and define in as much detail as possible the contact area between the intrusive and the limestone, where the intrusive material (ARG2-NC and ARG-3 argillic materials) would be located with the current LOM plan and, consequently, the overall stability from the top of the slope would deteriorate over time.

Considering these aspects, an opportunity was found to optimise the extraction of the east wall as shown in Figure 11. The plan is to mine and extract the upper part of the east wall, mainly the weakest materials that are the argillic, so that the optimised slope would be exposed in more competent materials such as limestone and potassium materials, as detailed in Figure 12.
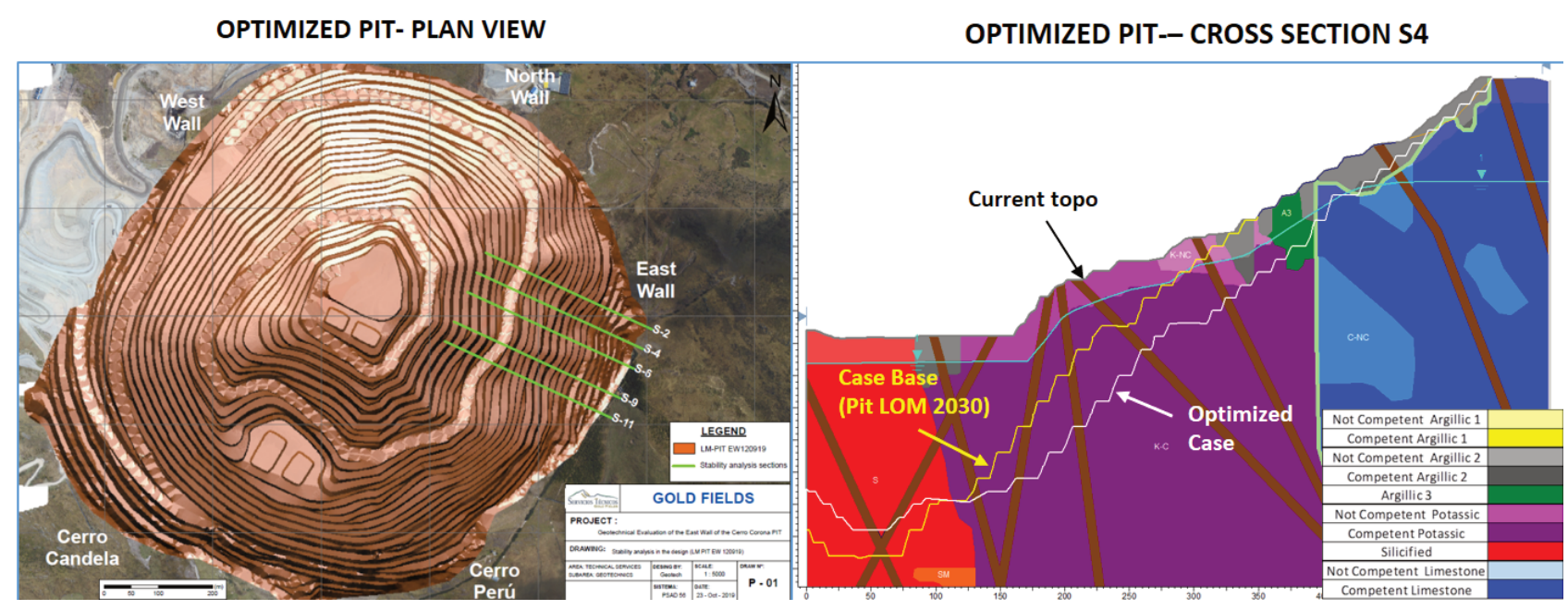

Figure 11 Optimised design plan for east wall, the left side shows the analysed cross-sections and the right side shows the detail of cross-section $\mathrm{S} 4$

Finally, the optimised design has been evaluated by stability analysis under the limit equilibrium method (general limit equilibrium method) and numerical analysis by resistance reduction factor (SRF), the results are shown in Table 7 and in Figures 12 and 13. The values obtained meet the acceptability criteria adopted for the Cerro Corona, mainly in the upper part where the final wall will be exposed to the competent limestone rock.

Table 7 Summary of stability analysis by equilibrium limit method and numerical analysis

\begin{tabular}{llccccc}
\hline Scenarios & \multicolumn{3}{c}{ Cross- } & \multicolumn{2}{c}{ Static analysis } & \multicolumn{2}{c}{ Pseudostatic analysis } & Critical SRF \\
section & $\begin{array}{c}\text { Obtained } \\
\text { FoS }\end{array}$ & $\begin{array}{c}\text { Minimum } \\
\text { acceptable } \\
\text { FoS }\end{array}$ & $\begin{array}{c}\text { Obtained } \\
\text { FoS }\end{array}$ & $\begin{array}{c}\text { Minimum } \\
\text { acceptable } \\
\text { FoS }\end{array}$ & $\begin{array}{c}\text { (numerical } \\
\text { method) }\end{array}$ \\
\hline \multirow{2}{*}{ Pit LOM 2030 } & S-4 & 1.47 & 1.3 & 1.25 & 1.05 & 1.47 \\
& S-9 & 1.33 & 1.3 & 1.14 & 1.05 & 1.47 \\
Optimised Pit & S-4 & 1.84 & 1.3 & 1.6 & 1.05 & 1.47 \\
& S-9 & 1.51 & 1.3 & 1.4 & 1.05 & 1.46 \\
\hline
\end{tabular}

FoS - Factor of Safety, SRF - strength reduction factor, LOM - life-of-mine. 

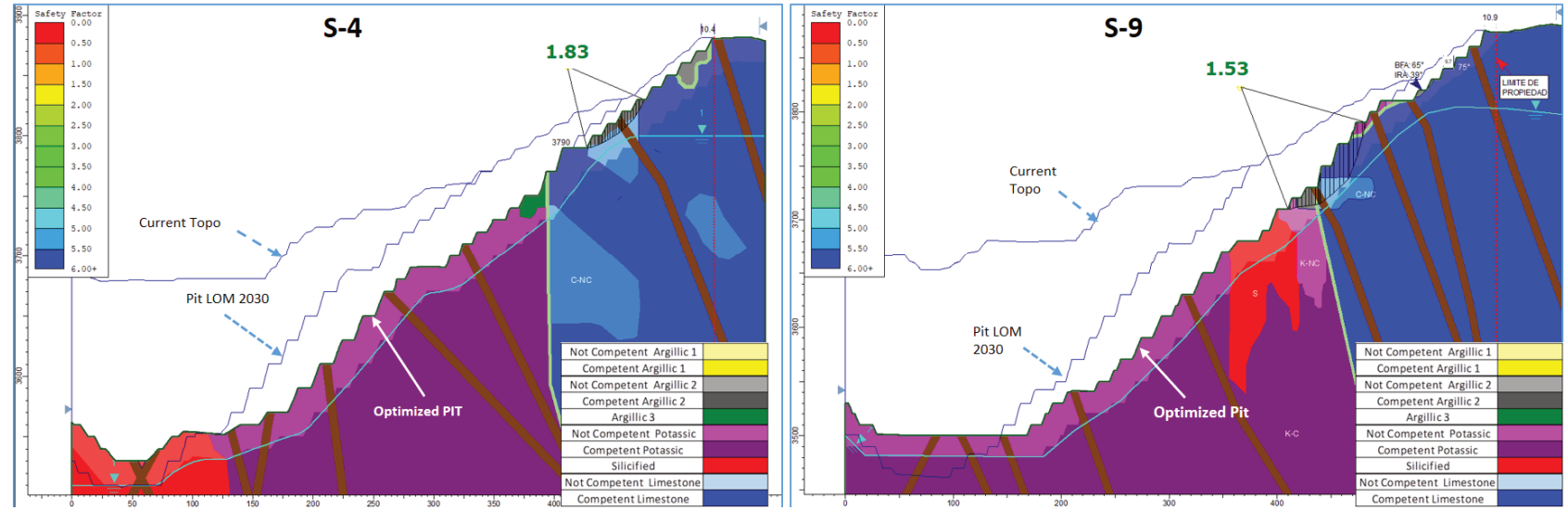

Figure 12 Stability analysis by equilibrium limit method, showing the results of cross-sections S-4 and S-9
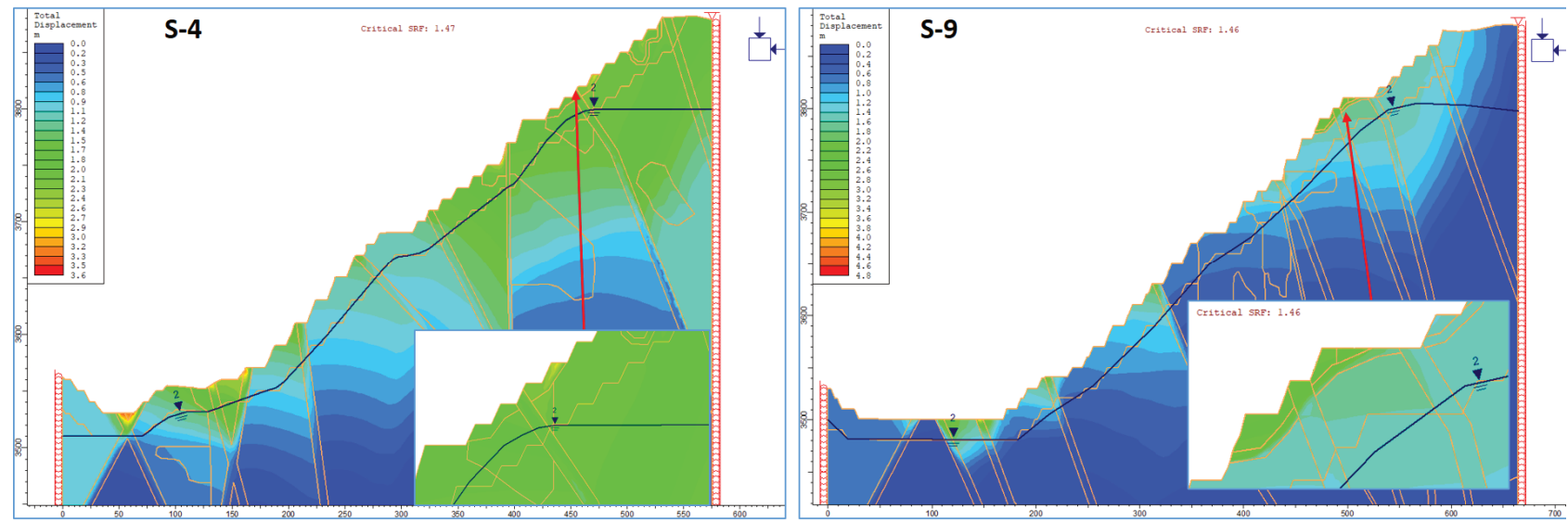

Figure 13 Numerical analysis using the strength reduction factor method showing the results of cross-sections S-4 and S-9

\section{Conclusion}

In general, the geotechnical monitoring, the update of the new 3D geotechnical block model, the comprehensive geotechnical study, and the drilling of sub-horizontal drains allowed geotechnical personnel to understand and define the geomechanical behaviour of the east wall.

Although there have been no notable drops in groundwater levels resulting from the drilling of the subhorizontal drains, it is believed that the vibrating wire piezometers installed are probably not located within the compartmentalised aquifer and are also not responding because the argillic lithology which has a very low permeability, each of which contribute to why descents of only $15 \mathrm{~m}$ have been observed.

Although good flows of the sub-horizontal drains have been observed to date, they still continue to flow with much lower flows, and the slope deformation rate has been considerably reduced to a level that has stabilised the east wall.

As the east wall has been stabilised, it has been decided to mine the upper part from level 3760 in order to excavate all argillic material to ensure the overall slope is situated in much more competent material, such as limestone.

Stability analyses performed by limit equilibrium meet the minimum acceptability criteria (FoS $>1.3$ ) static condition and (FoS $>1.05$ ) pseudo static condition. 
The results of the detailed geotechnical study have allowed the site to optimise the inter-ramp angle at the top of the slope by $2^{\circ}$, which was initially $46^{\circ}$ in the current LOM plan; where the argillic materials predominate.

Consequently, the new design has allowed the increase of the mineral reserve by $\sim 49 \mathrm{koz}$ of gold and $\sim 66.5 \mathrm{kt}$ of copper.

\section{Acknowledgement}

The authors thank the Gold Fields Executive Committee and the Technical Services Management for providing support in presenting the technical work.

\section{References}

Golder Associates 2019, 2D Stability Analysis East Wall Cerro Corona Pit, Technical Memorandum dated 28 March 2019 , Project No. 17921C4296-RevB.

Hoek, E, Carranza-Torres, CT \& Corkum, B 2002, 'Hoek-Brown failure criterion-2002 edition', R Hammah, W Bawden , J Curran \& M Telesnicki (eds), Proceedings of the Fifth North American Rock Mechanics Symposium, University of Toronto Press, Toronto, pp. 267-273.

Vásárhelyi, B \& Kovács, D 2017, 'Empirical methods of calculating the mechanical parameters of the rock mass', Periodica Polytechnica Civil Engineering, vol. 61, no. 1, pp. 39-50. 